\title{
Comparative Analysis of Apoptosis and Inflammation Genes of Mice and Humans
}

\author{
John C. Reed, ${ }^{1,3,4}$ Kutbuddin Doctor, ${ }^{1}$ Ana Rojas, ${ }^{1}$ Juan M. Zapata, ${ }^{1}$ \\ Christian Stehlik, ${ }^{1}$ Loredana Fiorentino, ${ }^{1}$ Jason Damiano, ${ }^{1}$ Wilfried Roth, ${ }^{1}$ \\ Shu-ichi Matsuzawa, ${ }^{1}$ Ruchi Newman, ${ }^{1}$ Shinichi Takayama, ${ }^{1}$ Hiroyuki Marusawa, ${ }^{1}$ \\ Famming Xu, ${ }^{1}$ Guy Salvesen, ${ }^{1}$ RIKEN GER Group ${ }^{2}$ and GSL Members, ${ }^{3,5}$ and \\ Adam Godzik ${ }^{1}$ \\ ${ }^{1}$ The Burnham Institute, La Jolla, California 92037, USA; ${ }^{2}$ Laboratory for Genome Exploration Research Group, RIKEN \\ Genomic Sciences Center (GSC), RIKEN Yokohama Institute, Suehiro-cho, Tsurumi-ku, Yokohama, Kanagawa, 230-0045, \\ Japan; ${ }^{3}$ Genome Science Laboratory, RIKEN, Hirosawa, Wako, Saitama 351-0198, Japan
}

\begin{abstract}
Apoptosis (programmed cell death) plays important roles in many facets of normal mammalian physiology. Host-pathogen interactions have provided evolutionary pressure for apoptosis as a defense mechanism against viruses and microbes, sometimes linking apoptosis mechanisms with inflammatory responses through $\mathrm{NF}_{\kappa} \mathrm{B}$ induction. Proteins involved in apoptosis and NFKB induction commonly contain evolutionarily conserved domains that can serve as signatures for identification by bioinformatics methods. Using a combination of public (NCBI) and private (RIKEN) databases, we compared the repertoire of apoptosis and NFKB-inducing genes in humans and mice from cDNA/EST/genomic data, focusing on the following domain families: (1) Caspase proteases; (2) Caspase recruitment domains (CARD); (3) Death Domains (DD); (4) Death Effector Domains (DED); (5) BIR domains of Inhibitor of Apoptosis Proteins (IAPs); (6) Bcl-2 homology (BH) domains of Bcl-2 family proteins; (7) Tumor Necrosis Factor (TNF)-family ligands; (8) TNF receptors (TNFR); (9) TIR domains; (10) PAAD (PYRIN; PYD, DAPIN); (11) nucleotide-binding NACHT domains; (12) TRAFs; (13) Hsp70-binding BAG domains; (14) endonuclease-associated CIDE domains; and (15) miscellaneous additional proteins. After excluding redundancy due to alternative splice forms, sequencing errors, and other considerations, we identified cDNAs derived from a total of 227 human genes among these domain families. Orthologous murine genes were found for 219 (96\%); in addition, several unique murine genes were found, which appear not to have human orthologs. This mismatch may be due to the still fragmentary information about the mouse genome or genuine differences between mouse and human repertoires of apoptotic genes. With this caveat, we discuss similarities and differences in human and murine genes from these domain families.
\end{abstract}

\begin{abstract}
Apoptosis is a form of programmed cell death that plays an important role in many facets of normal mammalian physiology, including embryological development, tissue homeostasis, and immune cell education (Metzstein et al. 1998). Defects in apoptosis regulation are implicated in the pathogenesis of multiple diseases, perhaps explaining why the study of apoptosis has emerged as one of the fastest growing areas of biomedical research in recent years (Thompson 1995; O'Reilly and Strasser 1999; Reed 2000).

Apoptosis also represents an important defense mechanism against pathogens. For example, cell suicide can provide a mechanism for depriving viruses of a host for replication, thus limiting viral spread (Miller 1997). Also, some of the families of proteins involved in apoptosis regulation participate in inflammatory responses to microbial pathogens. For instance, Caspase-family proteases are critical effectors of the apoptotic program, but some of these proteases are respon-
\end{abstract}

${ }^{4}$ Corresponding author.

E-MAIL jreed@burnham.org; FAX (858) 646-3194.

${ }^{5}$ Takahiro Arakawa, ${ }^{2}$ Piero Carninci, ${ }^{2,3}$ Jun Kawai, ${ }^{2,3}$ and Yoshihide Hayashizaki. ${ }^{2,3}$

Article and publication are at http://www.genome.org/cgi/doi/10.1101/ gr.1053803. sible for cleavage and activation of pro-inflammatory cytokines such as pro-Interleukin-1 $\beta$ and pro-Interleukin-18 (Thornberry and Lazebnik 1998). Similarly, some proteins involved in Caspase activation can also participate in triggering induction of $\mathrm{NF} \mathrm{B}$ family transcription factors, which regulate expression of numerous genes important for inflammatory responses, as well as innate and acquired immunity (Karin and Lin 2002). NFkB also regulates the expression of several genes involved in apoptosis control, for example, including expression of anti-apoptotic members of the Bcl-2, Inhibitor of Apoptosis (IAP), and Death Effector Domain (DED)-family of proteins (Reed 2002). Thus, the worlds of apoptosis and inflammation are often closely intertwined.

Proteins involved in apoptosis commonly contain evolutionarily conserved domains that can serve as signatures for identification, permitting application of bioinformatics techniques to analysis of families of apoptosis-regulatory proteins. Previously, we used bioinformatics approaches to mine human genomic and EST databases for the presence of expressed or putative genes containing signature domains associated with apoptosis, including the (1) Caspase protease fold; (2) Caspase-associated recruitment domain (CARD); (3) Death Domain (DD); (4) DED; (5) BIR domain of IAP proteins; (6) 
Bcl-2 homology (BH) domains of Bcl-2 family proteins; (7) nucleotide-binding NACHT domains; and (8) CIDE domains of apoptotic endonucleases, assembling this information into a database (http://apoptosis-db.org). In addition, several families of proteins containing other types of domains implicated either in the regulation of the core apoptotic machinery or in control of closely linked inflammatory response pathways were also organized, including (1) Tumor Necrosis Factor (TNF)-family ligands; (2) TNF receptors (TNFR); (3) TIR domains; (4) PAAD (Pyrin; PYD, DAPIN); (5) TRAFs; (6) REL $(\mathrm{NF} \kappa \mathrm{B})$ and IкB family proteins; and (7) BAG domains. These data for human genes thus provided a foundation for performing a comparative analysis with murine genes, including those identified from cDNA sequences deposited into either public databases at NCBI or a collection of cDNA sequence data from the RIKEN mouse transcriptome project (Kawai et al. 2001; Bono et al. 2002). A comparative analysis of human and mouse genes that comprise the aforementioned 15 domain families is provided here. The findings reveal some interesting and presumably functionally important speciesspecific differences among genes devoted to regulation of apoptosis and inflammation.

\section{RESULTS AND DISCUSSION}

After excluding alternative splice forms and adjusting for redundancy due to proteins that contain two or more of the domains of interest, sequences corresponding to human apoptosis and inflammation genes found apparent orthologous matches in either the public databases or RIKEN collection of murine cDNAs in 220 of 228 cases (96\%), including 10/11 Caspases; 18/23 CARD; 33/33 DD; 11/11 DED; 27/24 Bcl-2; 7/8 IAPs; 5/5 CIDEs; 12/19 PAAD; 16/20 NACHT; 18/14 TRAF-; and TRAF-related proteins (including TRAFs, TEFs, Meprins, Siah, and TRAF-binding proteins); 17/18 TNF-family ligands; 27/29 TNFRs; 14/16 TIR; 5/5 RELs; 7/8 IкBs; 6/6 BAG; and $33 / 35$ miscellaneous apoptosis-relevant proteins (Table 1). In 21 cases, murine orthologs of human genes that were absent from the public databases were represented in the RIKEN collection.

The automated annotation scheme revealed only five cases of novel murine proteins containing at least one of the signature domains of interest, which were not recognized previously. At the same time, few groups of human proteins systematically lack murine orthologs, implying that most of the genes of interest arose early in mammalian evolution. The final evaluation of such cases has to wait for the completion of the mouse genome. However, some species-specific differences are apparent between mouse and human that indicate recent amplification of certain genes. In several cases, these are represented by tandem extra copies of the relevant genes on the same chromosomes. A brief description of each of the domain families follows.

\section{Caspases}

Caspases represent a family of intracellular cysteine proteases that either induce apoptosis or that are required for proteolytic processing of certain pro-inflammatory cytokines (for review, see Thornberry and Lazebnik 1998). The cysteine protease fold that comprises the Caspase domain is composed of $\sim 20 \mathrm{kD}$ large and $\sim 10 \mathrm{kD}$ small catalytic subunits that are generated upon proteolytic cleavage from a proprotein precursor (Fesik 2000). The Caspases contain amino-terminal prodomains of variable length, with the upstream initiator
Table 1. Summary of Protein Domain Family Comparisons for Humans and Mice

\begin{tabular}{lrcc}
\hline Protein domain & Human & Mouse & Only in RIKEN \\
\hline Caspase & 11 & 10 & 0 \\
CARD $^{\mathrm{a}}$ & 23 & 18 & 5 \\
DED $^{\mathrm{a}}$ & 11 & 11 & 0 \\
DD & 33 & 33 & 4 \\
BIR & 8 & $7 \mathrm{~b}$ & 1 \\
BCl-2 & 24 & 27 & 0 \\
TNF-ligands & 18 & 17 & 0 \\
TNF-Rs & 29 & 27 & 1 \\
TIR & 14 & 16 & 0 \\
TRAF/TEF & 14 & 18 & 1 \\
PAAD & 19 & 12 & 6 \\
NACHT & 20 & 16 & 6 \\
REL & 5 & 5 & 0 \\
IKB & 8 & 7 & 0 \\
BAC & 6 & 6 & 3 \\
CIDE & 5 & 5 & 0 \\
Other & 35 & 33 & 0 \\
Total & 283 & 265 & 27 \\
Total (adjusted) & $(228)$ & $(221)$ & $(21)$ \\
\hline
\end{tabular}

Caspases containing CARDs or DEDs are excluded from the results $\left.{ }^{(}\right)$, but other domain families are not corrected for redundancy. In addition to caspases, 23 genes create redundancy due to the presence of more than 1 of the domains listed above. The total number of apoptosis and inflammation-relevant genes after adjustment for redundancy is also provided. Cases in which the data were available only in the RIKEN database are noted. Other genes include para-Caspase (MALT), the IAP-binding proteins, Smac (Diablo), HtrA2 (Omi), XAF, the mitochondrial proteins cytochrome c, AlF, and EndoG, the transcription factors, p53, p65, and $\mathrm{p} 73$, the Bcl-2-binding proteins R-Ras, Raf1, Prp1, ANT1, ANT2, ANT3, VDAC1, VDAC2, VDAC3, Beclin, BI-1, RTNx, Smn, Aven, Calcineurin-A, Calcineurin-B, Nip1, and Nip2 and the TRAFbinding proteins, I-TRAF (TANK), Trip, MIP-T3, TTRAP, KRC, TB2P, and TB2P-like.

bsee Table 6 for details of BIR-domain (IAP) proteins.

proteases generally having larger prodomains than downstream effector proteases. The larger prodomains serve as protein-interaction modules for controlling Caspase activation via the proposed induced proximity mechanism (Salvesen and Dixit 1999).

We found cDNAs representing 10 members of the Caspase family of cysteine proteases in mice, compared with 11 in humans (Table 2). Most striking is the absence of Caspase-10 in mice, this gene is also absent from all public databases. This member of the Caspase family is a close homolog of Caspase-8, containing two tandem copies of the DED in its amino-terminal prodomain, upstream of the carboxy-terminal catalytic domain that defines membership in this protease family. In humans, the Caspase- 8 and Caspase10 genes are located adjacent to each other on chromosome 2 , implying a recent gene duplication event. Other notable differences between human and mouse are found in Caspase- 4 and Caspase- 5 of man, which both appear to be orthologs of murine Caspase- 11 on the basis of phylogeny analysis. In humans, a predicted gene is found on chromosome 11 with striking nucleic acid sequence similarity to murine Caspase12 , but the predicted ORF contains a termination codon prior to the region encoding the catalytic domain (Fischer et al. 2002). All of the Caspases of mouse and human were deposited previously in the NCBI database. 
Table 2. Comparison of Caspases of Mice and Humans

\begin{tabular}{lcccc}
\hline Protein & Human & Mouse & NCBI gi & RIKEN \\
\hline Caspase-1 & + & + & 266322 & N/A \\
Caspase-2 & + & + & 2506262 & A630056A17 \\
Caspase-3 & + & + & 6753284 & 3110059017 \\
& & & & A830040C14 \\
Caspase-4 & + & - & Not present & Not present \\
Caspase-5 & + & - & Not present & Not present \\
Caspase-6 & + & + & 6753286 & 2610037 C10 \\
Caspase-7 & + & + & 6680850 & C130071H08 \\
Caspase-8 & + & + & 20847456 & N/A \\
Caspase-9 & + & + & 7656963 & D430036C13 \\
Caspase-10 & + & - & Not present & Not present \\
Caspase-11 & - & + & 6671682 & 903008106 \\
Caspase-12 & - & + & 6753278 & $5031429 D 02$ \\
Caspase-14 & + & + & 6753280 & C130060A16 \\
Para-Caspase & + & + & Not present & D430033E09 \\
\hline
\end{tabular}

The Caspases of humans and mice are compared. The murnine cDNAs found exclusively in the RIKEN database are indicated. (N/A) Not applicable, indicating the gene was already present at $\mathrm{NCBI}$ or that mice lack this gene. Note that Caspase-13 was subsequently recognized to represent a bovine CDNA that contaminated a human library. The human ortholog of murine Caspase12 is non-functional (Fischer et al. 2002). Representative genes are indicated by $\mathrm{NCBI}$ gi number corresponding to the protein record or RIKEN cDNA clone identification numbers. Minus sign indicates that a murine ortholog was not found.

Mouse cDNAs corresponding to a single para-Caspase (MALT) were also identified, suggesting that both mice and humans possess a single para-Caspase gene. The murine paraCaspase sequence was found in the RIKEN, but not the NCBI database. This protein is implicated in NFKB regulation (Uren et al. 2000).

\section{CARDs}

The CARD is a protein interaction module, generally comprised of a bundle of six $\alpha$-helices (Hofmann et al. 1997; Fesik 2000). This domain is commonly implicated in regulation of Caspases that contain CARDs in their amino-terminal prodomains (mouse Caspases 1, 2, 9, 11, and 12; human Caspases 1, $2,4,5$, and 9), or in regulation of NFkB activation.

In contrast to the 23 human genes encoding CARDcarrying proteins (excluding CARD-carrying Caspases), cDNAs representing only 18 of these were identified for mice in either the NCBI or RIKEN databases (Table 3). Present in both human and mouse were Apaf1; Arc (Nop30); ASC (TMS-1; PyCARD); Bcl-10 (CIPER, CARMEN, mE10, cE10, CLAP); Bimp1 (CARD10, Carma3); Bimp2 (CARD14, Carma2); Cardiak (RIP2, RICK); CARD6; CARP; cIAP1 (HIAP1, MIHB); cIAP2 (HIAP2, MIHC); Helicard (Mda5); NAC (NALP1, DEFCAP, CARD7); Nod1 (CARD4); Nod2 (CARD15); and RAIDD (CRADD). In addition, partial cDNAs were found that likely represent the murine orthologs of Bimp3 (CARD11; Carma1), and CLAN (Ipaf; CARD12), but the CARD-encoding region was missing from the sequences, and thus, caution must be exercised in ascribing these proteins to the CARD family. Missing from the available transcriptome of mice were CARD9, COP (Pseudo-ICE), COP2 (predicted genomic fragment), Iceberg, and TUCAN (Cardinal, CARD8, NDPP, Dakar). Five of the murine CARD-family members were found in the RIKEN, but not NCBI databases, for example, ARC (Nop30),
Table 3. Comparison of CARD-Family Proteins of Humans and Mice

\begin{tabular}{lccrl}
\hline Protein & Human & Mouse & NCBI gi & \multicolumn{1}{c}{ RIKEN } \\
\hline Apaf1 & + & + & 6857754 & 9530067 N01 \\
Arc & + & + & Not found & A230035L1 \\
ASC & + & + & 12963604 & 2310046 K21 \\
BCl-10 & + & + & 6753165 & 2700094 G04 \\
Bimp1 & + & + & 14326095 & 9930017 C23 \\
Bimp2 & + & + & 14326097 & D930010J19 \\
Bimp3 & + & + & Not found & A130067P1 \\
Cardiak & + & + & 20336736 & $2210420 D 18$ \\
CARD6 & + & + & Not found & D730008L1 \\
CARD9 & + & - & Not found & Not found \\
CARP & + & + & Not found & 2310047013 \\
cIAP1 & + & + & 2497239 & Not found \\
cIAP2 & + & + & 6680696 & Not found \\
CLAN & + & + & 20901567 & 9530011 P19 \\
COP & + & - & Not found & Not found \\
COP2 & + & - & Not found & Not found \\
Helicard & + & + & 18698980 & A430105A0 \\
Iceberg & + & - & Not found & Not found \\
NAC & + & + & 20346355 & Not found \\
Nod1 & + & + & Not found & F830007N1 \\
Nod2 & + & + & 22003911 & F830032C23 \\
RAIDD & + & + & 3608360 & D33023M1 \\
TUCAN & + & - & Not found & Not found \\
Total & 23 & 18 & - & 5 \\
\hline
\end{tabular}

The CARD-family proteins of humans and mice are compared. The murine CDNAs found exclusively in the RIKEN database are indicated. (N/A) Not applicable, indicating the CDNA was already present at NCBI. Representative genes are indicated by NCBI gi or RIKEN clone identification numbers. The following proteins have alternative names: Arc (Nop30), ASC (TMS-1; PYCARD), Bcl-10 (CIPER, CARMEN, mE10, cE10, CLAP), Bimp1 (CARD10, Carma3), Bimp2 (CARD14, Carma2), Bimp3 (CARD11, Carma1), Cardiak (RICK, RIP2), CIAP1 (HIAP2, MIHB), CIAP2 (HIAP1, MIHC), CLAN (Ipaf, CARD12), COP (Pseudo-ICE), NAC (NALP1, DEFCAP, CARD7), Nod1 (CARD4), Nod2 (CARD15), RAIDD (CRADD), TUCAN (Cardinal, CARD8, NDPP, Dakar). The number of cases in which CDNAs were found uniquely in the RIKEN database is indicated $(n=5)$. A minus sign $(-)$ appears if a murine ortholog was not found.

Bimp3, CARD6, CARP, and Nod1. Although some reports have suggested the presence of a CARD in the protein CIITA (Nickerson et al. 2001), our analysis using various structureprediction programs such as FFAS, RPS-BLAST, CDART, and SMART failed to confirm this hypothesis, thus, it was not included here (Table 3).

The absence of Iceberg, COP, and COP2 in the available mouse cDNA and genomic collections, if true, suggests that humans have evolved additional mechanisms for controlling activation of Caspase- 1 . These proteins are comprised essentially of just a CARD with strong sequence similarity to the CARD found in pro-Caspase-1, and they have been shown in the cases of Iceberg and COP (Pseudo-Caspase) to bind and inhibit activation of pro-Caspase-1 (Humke et al. 2000; Druilhe et al. 2001; Lee et al. 2001). Similarly, the absence of TUCAN in mice suggests an additional level of complexity to regulating Caspase-9 in humans, as this CARD-containing protein reportedly binds and suppresses activation of Caspase-9 (Pathan et al. 2001). Species-specific differences in Caspase-9 regulation have been reported previously (Reed et al. 2000; Rodriguez et al. 2000). 


\section{DEDs}

DED is a protein-interaction module similar to the CARD, which is generally comprised of a $6 \alpha$-helical bundle (Eberstadt et al. 1998). DED-containing proteins have been implicated in apoptosis regulation via interactions with DEDcontaining Caspases (Caspase-8 and Caspase-10 in human; Caspase-8 in mouse). Excluding DED-containing Caspases, cDNAs representative of 11 DED-family genes were identified in humans and orthologous sequences were found in all 11 of these in mice (Table 4). The DED-containing proteins listed in Table 4 comprise proteins with classical DEDs, as well as proteins with DED-like domains.

\section{DDs}

The DD is another protein-interaction module belonging to the same superfamily that includes the CARD, DED and PAAD (PYRIN, PYD, DAP; Fesik 2000). This domain is commonly implicated in either NFKB induction or Caspase activation, typically involving interactions with members of the TNFfamily of cytokine receptors (Ashkenazi and Dixit 1998). Of the 33 DD-containing proteins recognized in human, 32 orthologs and one novel DD-containing protein were represented in the cDNA sequence data available at NCBI and RIKEN (Table 5). At the time of our analysis, only four of the DD-family proteins were found uniquely in the RIKEN database (Ankyrin-2, IRAK2, MALT, and TRADD).

Absent from the available mouse data was DR4, one of the receptors for TRAIL (Apo2L), an apoptosis-inducing member of the TNF family. In humans, DR4 and DR5 are highly homologous proteins encoded by tandem genes on chromosome $8 \mathrm{p} 21$, both of which bind TRAIL and activate Caspases involved in apoptosis. Thus, it appears that a recent gene duplication event in humans has increased the complexity of the DD-containing TRAIL receptors.

Mouse ESTs encoding a predicted 228 amino-acid protein containing a DD were identified in both the NCBI (GenBank AV149215) and RIKEN (2610311B09) databases. The DD of this protein shares $36 \%$ amino-acid sequence identity (55\% sequence similarity) with the DD of p75-NTR, and is

\begin{tabular}{|c|c|c|c|c|}
\hline Protein & Human & Mouse & NCBI gi & RIKEN \\
\hline Caspase 8 & + & + & 3193167 & $\mathrm{~N} / \mathrm{A}$ \\
\hline Caspase 10 & + & - & Not found & Not found \\
\hline DEDD & + & + & 6755835 & $1700056 \mathrm{~K} 21$ \\
\hline DEDD2 & + & + & 20126796 & 2410050E11 \\
\hline FADD & + & + & 6753812 & $6030422 \mathrm{~N} 02$ \\
\hline FLIP & + & + & 2253683 & $\mathrm{~N} / \mathrm{A}$ \\
\hline PEA-15 & + & + & 2498751 & E430038103 \\
\hline BAP31 ${ }^{a}$ & + & + & 12805281 & 2610021E10 \\
\hline $\mathrm{BAR}^{\mathrm{a}}$ & + & + & 12851406 & $3010001 \mathrm{~A} 0$ \\
\hline DAP- $3^{a}$ & + & + & 18043506 & 6430514F02 \\
\hline FLASH $^{a}$ & + & + & 4754905 & $2610104 C 23$ \\
\hline HIP-1 ${ }^{\text {a }}$ & + & + & 17028404 & E230016G06 \\
\hline $\mathrm{HIPPI}^{\mathrm{a}}$ & + & + & 20127155 & B930036N12 \\
\hline Total & 13 & 12 & - & 0 \\
\hline
\end{tabular}

${ }^{a}$ DED-like domains (Pseudo-DEDs).

The DED-family proteins of humans and mice are compared. (N/A) Not applicable or that mice lack that gene. Minus sign indicates that a murine ortholog was not found.

\begin{tabular}{|c|c|c|c|c|}
\hline Protein & Human & Mouse & NCBI gi & RIKEN \\
\hline Ankyrin-1 & + & + & 1168457 & N/A \\
\hline Ankyrin-2 & + & + & Not found & A930028N13 \\
\hline Ankyrin-3 & + & + & 11276933 & $9530086 C 08$ \\
\hline DAP-Kinase & + & + & 18204817 & $2310039 \mathrm{H} 24$ \\
\hline DR3 & + & + & 14719438 & $\mathrm{~N} / \mathrm{A}$ \\
\hline DR4 & + & - & Not found & Not found \\
\hline DR5 & + & + & 5815401 & A530056N19 \\
\hline DR6 & + & + & 16741137 & A830037A05 \\
\hline EDAR & + & + & 6753714 & 1200003 K04 \\
\hline EDARADD & + & + & 19526479 & A630089O21 \\
\hline FADD & + & + & 6753812 & $6030422 \mathrm{~N} 02$ \\
\hline Fas & + & + & 6679751 & $0610012 \mathrm{D} 23$ \\
\hline IRAK-1 & + & + & 15214058 & В230327C 20 \\
\hline IRAK-2 & + & + & Not found & $4732448 K 15$ \\
\hline IRAK-4 & + & + & 20219012 & 4732460109 \\
\hline IRAK-M & + & + & 12852834 & $4833428 C 11$ \\
\hline MADD & + & + & 13096910 & $9630059 \mathrm{~K} 23$ \\
\hline MALT-1 & + & + & Not found & D430033E09 \\
\hline MyD88 & + & + & 6754772 & G430132D13 \\
\hline NF-кB-1 & + & + & 6679044 & F830007L24 \\
\hline NF-кB-2 & + & + & 9506921 & N/A \\
\hline NGFR & + & + & 15082265 & $\mathrm{~A} 030014 \mathrm{~A} 01$ \\
\hline NMP-84 & + & + & 19353206 & $6430411 N 16$ \\
\hline NRDD & - & + & 20895338 & 1810013 K01 \\
\hline Pidd & + & + & 12083587 & 1200011D09 \\
\hline RAIDD & + & + & 6753516 & D330023M19 \\
\hline RIP & + & + & 6677753 & 5830469012 \\
\hline TNFR1 & + & + & 135960 & $\mathrm{~N} / \mathrm{A}$ \\
\hline Tradd & + & + & Not found & 9130005 N23 \\
\hline UNC5H1a & + & + & 23346571 & N/A \\
\hline UNC5H1b & + & + & 23346571 & N/A \\
\hline UNC5H2 & + & + & 12857776 & 6330415E02 \\
\hline UNC5H3 & + & + & 6678505 & $6030473 \mathrm{H} 24$ \\
\hline UNC5H4 & + & + & 23346575 & N/A \\
\hline Total & 33 & 33 & - & 4 \\
\hline
\end{tabular}

The DD-family proteins of humans and mice are compared. Murine cDNAs found uniquely in the RIKEN database are indicated. (N/A) Not applicable, indicating the data was already present at NCBI. Minus sign indicates murine gene not found.

preceded by a predicted transmembrane (TM) domain, indicative of an integral membrane protein. Homologous ESTs were found in humans (GenBank AI688486; BE839192), but the predicted ORFs contained a termination codon preceding the DD-encoding region, indicating that the predicted human protein lacks a DD. We have tentatively termed the predicted mouse protein, NRDD, for NTR-related death domain.

\section{IAPs}

The IAP-family proteins function as apoptosis suppressors (Deveraux and Reed 1999). All members of this family contain at least one copy of a zinc-binding fold, termed the BIR domain (Miller 1999). Several IAPs have been reported to directly bind and suppress Caspase-family proteases (Deveraux and Reed 1999). Humans have genes encoding IAP-family proteins, including Naip, cIAP1, cIAP2, XIAP, Survivin, Apollon (BRUCE), ML-IAP (Livin; K-IAP), and ILP2 (TsIAP). Murine cDNAs corresponding to seven of these IAP-family proteins were identified in either the NCBI or RIKEN databases (Table 6), with ILP2 missing from the available mouse transcriptome data. Sequence information for ML-IAP was uniquely found in the RIKEN database at the time of analysis, whereas the 
Table 6. Comparison of IAP and IAP-Related-Family Proteins of Humans and Mice

\begin{tabular}{lccrl}
\hline Protein & Human & Mouse & NCBI & \multicolumn{1}{c}{ RIKEN } \\
\hline NAIP (BIRC1) & + & + & 6679007 & N/A \\
CIAP1 (BIRC2) & + & + & 6680695 & E130019N06 \\
CIAP2 (BIRC3) & + & + & 6680697 & N/A \\
XIAP (BIRC4) & + & + & 20983625 & N/A \\
Survivin (BIRC5) & + & + & 6753089 & 5830459 C16 \\
Apollon (BIRC6) & + & + & 20985107 & B230120j06 \\
ML-IAP (BIRC7) & + & + & Not found & E130019N06 \\
ILP2 (BIRC8) & + & - & Not found & N/A \\
Smac (DIABLO) & + & + & 8953909 & $4933428 M 04$ \\
HtrA2 & + & + & 5739487 & $2610024 J 09$ \\
XAF & + & + & Not found & B530033B21
\end{tabular}

The IAPs and IAP-agonists (Smac; HtrA2; XAF) of humans and mice are compared. The murine CDNAs found exclusively in the RIKEN database are indicated. (N/A) Not applicable, indicating the data was already present at NCBI. In mice, approximately six NAIP genes have been identified in a cluster on chromosome 13. At least three of these are transcriptionally active and likely to encode functional proteins (Huang et al. 1999; Endrizzi et al. 2000).

other IAPs were found in NCBI. Interestingly, multiple tandem copies of naip-related genes have been found on mouse chromosome 13 (Endrizzi et al. 2000). In contrast to humans that express only one NAIP gene (Roy et al. 1995; La Casse et al. 1998), mice appear to express at least three versions of the NAIP protein from distinct genes (see legend to Table 6 for details).

Several IAP antagonists have been identified in humans, including SMAC (Diablo), Omi (HtrA2), and XAF. ESTs or cDNAs corresponding to all of these were observed in mice, with XAF sequence data uniquely found in the RIKEN databases.

\section{$\mathrm{Bcl}-2$}

Proteins of the Bcl-2 family are critical regulators of apoptosis, whose functions included governing mitochondriadependent steps in cell death pathways (Green and Reed 1998; Kroemer and Reed 2000). EST and cDNA data corresponding to 24 human and 27 mouse Bcl-2 family genes were identified (Table 7). These included (1) the multidomain members of the family, which contain Bcl-2 Homology (BH) domains, $\mathrm{BH} 1, \mathrm{BH} 2, \mathrm{BH} 3$, and (sometimes) $\mathrm{BH} 4$ (Bcl-2, BclX, Mcl1, Bcl-W, Bf11 [A1], Bcl-B, Diva [Boo], Bax, Bak, Bok [Mtd]), which have been documented or predicted to share structural similarity with the $\alpha$-helical pore-forming domains of certain bacterial toxins (Fesik 2000); (2) Bcl- $\mathrm{G}_{\mathrm{L}}$, which possess $\mathrm{BH} 2$ and $\mathrm{BH} 3$ domains (Guo et al. 2001); (3) several BH3only proteins (Bad, Bid, Bim [Bod], Bmf, Bik [Blk], Noxa [APR], Puma, Hrk [Dp5], [Huang and Strasser 2000]) (4) proteins with BH3-like domain (Nip3 [Bnip3], Nix [Nip3L], Map1, p193; Chen et al. 1999), and (5) a protein containing a putative BH2 domain (Bcl2L12; Scorilas et al. 2001). The human ortholog of mouse Diva (Boo) appears to be Bcl-B, on the basis of phylogeny analysis (data not shown). Interestingly, four copies of the $\mathrm{A} 1$ gene of mice (known as Bfl1 in humans) have been identified. Three of these A1 genes (A1a, Bid) are closely linked on chromosome 9, (NCBI Locus ID12044, ID12045, and ID12047), indicating a recent gene-amplification event in mice (Orlofsky et al. 2002). Bcl-2 family genes are well known

\begin{tabular}{|c|c|c|c|c|}
\hline Protein & Human & Mouse & NCBI gi & RIKEN \\
\hline $\mathrm{BCl}-2$ & + & + & 231633 & C430015F12 \\
\hline $\mathrm{BCl}-\bar{x}$ & + & + & 2493277 & $\mathrm{~N} / \mathrm{A}$ \\
\hline Mcl-1 & + & + & 6678824 & N/A \\
\hline Bcl-w & + & + & 2493279 & 4930488D08 \\
\hline \multicolumn{5}{|l|}{$\mathrm{BCl}-\mathrm{B} / \mathrm{Boo} /$} \\
\hline Diva & + & + & 7304927 & N/A \\
\hline A1 a/Bfl-1 & + & + & 729772 & N/A \\
\hline $\mathrm{A} 1 \mathrm{~b}$ & - & + & 20934613 & N/A \\
\hline A1c & - & + & 20962531 & N/A \\
\hline A1d & - & + & 20958972 & $\mathrm{~N} / \mathrm{A}$ \\
\hline Bax & + & + & 728946 & $2810443 \mathrm{M} 09$ \\
\hline Bak & + & + & 2493276 & F630041J23 \\
\hline Bok/Mtd & + & + & 7949082 & N/A \\
\hline \multicolumn{5}{|l|}{ Mil-1/ } \\
\hline Bcl-Rambo & + & + & 20342196 & E430016C20 \\
\hline Bcl-G & + & + & 20834553 & 2210008009 \\
\hline Bik & + & + & 13277643 & N/A \\
\hline Hrk/Dp5 & + & + & 2498468 & $\mathrm{~N} / \mathrm{A}$ \\
\hline Bim/Bod & + & + & 18202064 & C230069E03 \\
\hline Bad & + & + & 2493288 & $\mathrm{~N} / \mathrm{A}$ \\
\hline Bid & + & + & 2493286 & 5730509E14 \\
\hline Puma & + & + & 20820326 & N/A \\
\hline Bmf & + & + & 15545991 & D330026D15 \\
\hline Noxa & + & + & 10946832 & A830041017 \\
\hline Nip3/Bnip3 & + & + & 6093508 & 2410015 N02 \\
\hline Nix/Nip3L & + & + & 7227912 & 9130410 L09 \\
\hline Bcl-L12 & + & + & 20336330 & 5430429M05 \\
\hline MAP-1 & + & + & 11139671 & $2610209 C 10$ \\
\hline p193 & + & + & gil20962014l & 2510004 L20 \\
\hline Total & 24 & 27 & - & 0 \\
\hline
\end{tabular}

(N/A) Not applicable because cDNA clone was already found at NCBI. Minus sign indicates that additional human orthologs were not found.

for production of splice variants that produce proteins, sometimes having opposing functions (e.g., $\mathrm{Bcl}-\mathrm{X}_{\mathrm{L}}$ vs $\mathrm{Bcl}-\mathrm{X}_{\mathrm{S}}$ ) (Boise et al. 1993; Reed 1999). Humans and mice appeared to share many of these splicing variants (data not shown).

In humans, 18 putative Bcl-2-binding proteins have been described that lack sequence similarity with Bcl-2 and its relatives, including R-Ras, Raf1, Prp1, BAG1, Flip, ANT1, ANT2, ANT3, VDAC1, VDAC2, BAR, BI-1, RTN-x, Smn, Apaf1, Aven, Nip1, and Nip2. ESTs or cDNAs corresponding to 16 of these 18 proteins were identified for mice. Only Adenine Nucleotide Translocator-3 (ANT3) and RTN-x were absent from the available murine data (data not shown).

\section{TNF-Family Ligands}

Many TNF-family cytokines regulate pathways implicated in either suppression or induction of apoptosis (Baud and Karin 2001; Locksley et al. 2001). Humans have 18 genes encoding proteins that contain a conserved carboxy-terminal domain spanning 150 amino acids, which is termed the TNF homology domain (THD). This domain is involved in ligand trimerization and receptor binding. Most family members contain predicted TM domains and are trimeric Type II transmembrane proteins, in which the carboxyl terminus is predicted to be oriented toward the outside of the cell and the amino terminus toward the cell interior. Some TNF-family ligands are released from the cell surface by proteolysis. ESTs 
or cDNAs corresponding to all of these TNF-family ligands, except AITRL, were identified in the mouse databases (Table $8)$. Thus, this family of proteins is highly conserved between humans and mice.

\section{TNF-Family Receptors}

The receptors for TNF-family ligands contain a conserved cysteine-rich domain (CRD) present in one to four copies, typically preceded by a hydrophobic leader peptide sequence and followed by a TM domain, indicative of Type I transmembrane proteins that are sorted to the cell surface (Locksley et al. 2001). Some of these receptors lack a membrane-anchoring TM domain and are secreted from cells, whereas others are released from the cell surface by proteolysis. Humans contain 29 genes encoding TNF-family receptors, including 8 that contain a DD in their cytosolic tails. Sequence data from the NCBI and RIKEN databases demonstrated the presence of 25 mouse TNF-family receptors with orthologs in humans, as well as 2 additional receptors (SOBa and $\mathrm{SOBb}$ ) found only in mice (Table 9). Missing from the mouse databases were the TRAIL receptor DR4 (as mentioned above), as well as two TRAIL decoy receptors DcR1 (TNFRsF10c) and DcR2 (TNFRsF10d), and the FasL decoy receptor DcR3 (TNFRsF6b) that possess the extracellular ligand-binding domain but lack signaling-transducing cytosolic domains. Thus, humans may have evolved a greater diversity of signaling transducing (DR4 and DR5) and decoy (DcR1 and DcR2; vs. only OPG in mouse) receptors for TRAIL, allowing greater fine tuning of responses to this TNF-family ligand. Analogously, no mouse ESTs or cDNAs were found that encode the decoy receptor, DcR3, which competes for binding to FasL (TNFSF6; Roth et al. 2001), LIGHT (TNFSF14; Yu et al. 1999), and TL1A (TNFSF15; Migone et al. 2002).

Interestingly, although the ligand was not present for mouse, ESTs encoding the mouse homolog of the TNF-family receptor AITR were identified, suggesting either that eventually the corresponding murine ligand will be identified or that

Table 8. Comparison of TNF-Superfamily of Humans and Mice

\begin{tabular}{llccrl}
\hline Standard & Common & Human & Mouse & NCBI gi & \multicolumn{1}{c}{ RIKEN } \\
\hline TNFSF1 & LT $\alpha$ & + & + & 387407 & A630048P10 \\
TNFSF2 & TNF & + & + & 7305585 & N/A \\
TNFSF3 & LT $\beta$ & + & + & 6678730 & N/A \\
TNFSF4 & OX40L & + & + & 6678473 & N/A \\
TNFSF5 & CD40L & + & + & 15011846 & N/A \\
TNFSF6 & FASL & + & + & 6753818 & A430069F14 \\
TNFSF7 & CD27L & + & + & 6755839 & N/A \\
TNFFF8 & CD30L & + & + & 6678387 & 5830454L09 \\
TNFFF9 & 4-1BBL & + & + & 6678389 & N/A \\
TNFFF10 & TRAIL & + & + & 6678431 & N/A \\
TNFSF11 & RANKL & + & + & 6755833 & N/A \\
TNFSF12 & TWEAK & + & + & 2707221 & A930010H24 \\
TNFSF13 & APRIL & + & + & 12844355 & $2310026 N 09$ \\
TNFSF13b & BAFF & + & + & 13124571 & $9330158 D 20$ \\
TNFSF14 & LIGHT & + & + & 9507195 & N/A \\
TNFSF15 & TL1A & + & + & 21745394 & N/A \\
TNFSF18 & AITRL & + & - & Not found & Not found \\
N/A & EDA-A1/A2 & + & + & 6753712 & N/A \\
& & & & 5734458 & \\
Total & & 18 & 17 & - & 0 \\
& & & + & & \\
\hline
\end{tabular}

(N/A) Not applicable because CDNA was already found at NCBI. Minus sign indicates that a murine ortholog could not be found. another member of the TNF family can bind this receptor, analogous to some TNF-family ligand/receptor combinations in which more than one ligand competes for a given receptor (Kovacsovics et al. 2002).

\section{TIRs}

Toll-like receptors (TLRs) play important roles in innate immunity (Aderem and Ulevitch 2000). These Type I transmembrane receptors contain Leucine Rich Repeat (LRR) domains in their extracellular region, which bind various molecules made by microbial pathogens, as well as certain endogenous proteins such as heat-shock proteins when released by cell lysis (Wagner 2001; Vabulas et al. 2002). The TIR domain represents a $\sim 130$ amino acid fold related to flavodoxin consisting of a 5 -strand parallel $\beta$-sheet surrounded by two layers of parallel $\alpha$-helices (Xu et al. 2000). The TIR domain is found in the cytosolic (intracellular) tails of TLRs, as well as in certain intracellular adapter proteins that interact with TLRs in the context of transducing signals important for innate immunity, including activation of NFкB (Silverman and Maniatis 2001). Of the 14 TIR-containing proteins identified previously in humans (IL-1R, TLR1, TLR2, TLR3, TLR4, TLR5, TLR6, TLR7, TLR8, TLR9, TLR10, MyD88, and Mal [TIRAP]), orthologous sequences were found for 13 in mice, the sole exception being TLR10 (Table 10).

\section{TRAFs/TEFs}

TRAFs constitute a family of adapter proteins that share an $\sim 180$ amino acid fold, the TRAF domain, which is comprised of a bundle of eight $\beta$-strands, preceded by an $\alpha$-helical segment that forms coiled-coil interactions, stabilizing these domains into trimers (Chung et al. 2002). TRAFs bind the cytosolic (intracellular) regions of TNF-Rs, certain adapter proteins involved in TNF-R signaling (Tradd), and some IAP-family members. They link these proteins to downstream protein kinases involved in induction of NFKB and Jun aminoterminal kinase (JNKs), among other signaling proteins and pathways (Arch et al. 1998; Bradley and Pober 2001; Chung et al. 2002). Six TRAFs have been identified in humans, with clear orthologs found for all of these in mice (Table 11). Although lacking the TRAF-domain, six TRAF-binding proteins have also been described in humans, including I-TRAF (TANK) (Cheng and Baltimore 1996; Rothe et al. 1996), Trip (Lee et al. 1997), MIP-T3 (Ling and Goeddel 2000), TTRAP (Pype et al. 2000), KRC (Oukka et al. 2002), TB2P (Kanamori et al. 2002), and TB2P-like (J. Zapata, J.C. Reed, unpubl.). Murine orthologs for all of these are evident in murine databases, with partial clones of MIP-T3 (3930402D05) and T2BP-like (9830144P17) found exclusively in the RIKEN database.

The $\beta$-strand region of the TRAF domain (so-called, C-TRAF domain) shares documented or predicted structural similarity with a variety of other types of proteins, including Meprins (Uren and Vaux 1996), Siah-family proteins (Tartaglia et al. 1991; Reed 2002), and the TEF (TRAFEncompassing Factors) TEF1 (Ubiquitin-Specific Protease-7 [USP7]), TEF2 (SPOP), and TEF3 (Mulibrey Nanism [MUL]; Zapata et al. 2001). A total of eight human proteins have been identified that contain these TRAF-like folds, including Me- 
Table 9. Comparison of TNF-Receptors Superfamily of Humans and Mice

\begin{tabular}{|c|c|c|c|c|c|}
\hline Standard & Common & Human & Mouse & NCBI gi & RIKEN \\
\hline TNFRSF1A & TNFR1 & + & + & 13435460 & $\mathrm{~N} / \mathrm{A}$ \\
\hline TNFRSF1B & TNFR2 & + & + & 135963 & $1300002 \mathrm{~A} 12$ \\
\hline TNFRSF3 & LT $\beta R$ & + & + & 1729988 & 9030221D21 \\
\hline TNFRSF4 & OX40 & + & + & 1352652 & N/A \\
\hline TNFRSF5 & CD40 & + & + & 6755829 & F830034E13 \\
\hline TNFRSF6 & Fas & + & + & 119834 & $0610012 \mathrm{D} 23$ \\
\hline TNFRSF6B & DcR3 & + & - & Not found & Not found \\
\hline TNFRSF7 & CD27 & + & + & 729080 & $\mathrm{~N} / \mathrm{A}$ \\
\hline TNFRSF8 & CD30 & + & + & 6678385 & N/A \\
\hline TNFRSF9 & $4-1 \mathrm{BB}$ & + & + & 112795 & 5031438 N10 \\
\hline TNFRSF10A & DR4 & + & - & Not found & Not found \\
\hline TNFRSF10B & DR5 & + & + & 11990627 & A530056N19 \\
\hline TNFRSF10C & DcR1 & + & - & Not found & Not found \\
\hline TNFRSF10D & DcR2 & + & - & Not found & Not found \\
\hline TNFRSF11A & RANK & + & + & 6678381 & $\mathrm{~N} / \mathrm{A}$ \\
\hline TNFRSF11B & OPG & + & + & 6679174 & N/A \\
\hline TNFRSF12 & DR3 & + & + & 14719438 & N/A \\
\hline TNFRSF13 & $\mathrm{TACl}$ & + & + & 10946668 & N/A \\
\hline TNFRSF14 & HVEM & + & + & 18381074 & N/A \\
\hline TNFRSF16 & NGFR & + & + & 15082265 & A030014A01 \\
\hline TNFRSF17 & BCMA & + & + & 6755823 & $9030212 \mathrm{~K} 17$ \\
\hline TNFRSF18 & AITR & + & + & 13878819 & A430104A12 \\
\hline TNFRSF19 & TROY & + & + & 14389429 & $2310021 \mathrm{M} 07$ \\
\hline N/A & EDAR & + & + & 6753714 & $1200003 \mathrm{~K} 04$ \\
\hline N/A & XEDAR & + & + & Not found & C330006C18 \\
\hline N/A & BAFF-R & + & + & 19070549 & $\mathrm{~N} / \mathrm{A}$ \\
\hline $\mathrm{N} / \mathrm{A}$ & TWEAK-R & + & + & 7305059 & 1600012005 \\
\hline N/A & DR6 & + & + & 16418471 & A830037A05 \\
\hline $\mathrm{N} / \mathrm{A}$ & RELT & + & + & 14596799 & E430021K24 \\
\hline N/A & SOBa & - & + & 12963781 & $2810028 \mathrm{~K} 06$ \\
\hline N/A & $\mathrm{SOBb}$ & - & + & 13195696 & N/A \\
\hline Total & & 29 & 27 & - & 1 \\
\hline
\end{tabular}

(N/A) Not applicable because CDNA was already found at NCBI. Minus sign indicates that either a human or a murine ortholog could not be found.

\section{PAADs/PYRINs}

The PAAD domain (also known as PYRIN, PYD, DAPIN) is comprised of a bundle of five or six $\alpha$-helices (Martinou and Green 2001; Pawlowski et al. 2001; Staub et al. 2001; Bertin and DiStefano 2000; Espejo et al. 2002), and represents another branch of the DD superfamily, which contains DDs, DEDs, and CARDs. Although the functions of PAAD-containing proteins are still being elucidated, recent data suggest they operate as homotypic proteininteraction motifs that mediate interactions with proteins involved in activation of inflammatory Caspases (e.g., Caspase-1) and NFкB (Fiorentino et al. 2002; Manji et al. 2002; Perfettini et al. 2002; Srinivasula et al. 2002; Wang et al. 2002). Hereditary mutations in some genes encoding PAAD-family proteins have been implicated in autoimmune and hyperinflammatory syndromes, further supporting a role for these proteins in regulating inflammatory responses (Consortium 1997; Hoffman et al. 2001).

In humans, 19 candidate PAAD-family genes have been identified, including ASC (PyCARD), NAC (NALP1, PYPAF1, DEFCAP, CARD7), Cryopyrin (PYPAF1, NALP3), Pyrin (Marenostrin), AIM2, IFP16, POP1 (ASC2), POP2, and PAN1 through PAN11 (also known as NALPs and PYPAFs), (Table 12). In some cases, the PAAD domains are present as the only motifs within these proteins (POP1, POP2), but in most instances, the PAAD is combined with various other domains, including CARDs (ASC, NAC), nucleotide-binding NACHT domains (see below) (NAC, Cryopyrin, PAN1-PAN11), LRRs (NAC, prin-1a and Meprin-1b on chromosomes 6p21 and 18q12, respectively (Uren and Vaux 1996), Siah-1 and Siah-2 (Hu et al. 1997), TEF1, TEF2, and TEF3 (Zapata et al. 2001), and TEF4 (J. Zapata, J.C. Reed, unpubl.). The human TEF4 protein is highly similar (76\% identical) to TEF2 (SPOP), containing a TRAF-like domain and a POZ domain. In mice, orthologs for all of these human proteins were found in the EST/cDNA data, with the exception of TEF4. Partial cDNAs encoding mouse TEF3 were uniquely found in the RIKEN database (Table 10). Although lacking an ortholog of TEF4, cDNAs encoding TEF2/ TEF4-like proteins were identified in mice that appear to arise from different genes, termed mouse TEF5, TEF6, TEF7, and TEF8 (Table 11). Phylogeny analysis suggests that these TEF2/ TEF4-like proteins are not strictly orthologous to their human counterparts. Why mice have evidently evolved several TEF2/ TEF4-related genes is unclear, and awaits elucidation of the functions of these proteins. Mice also contain an additional Siah-family gene relative to humans, apparently as a result of gene duplication, in which the resulting protein products (Siah1a, Siah1b) share 98\% amino acid sequence identity (Della et al. 1993). The functions of most of these proteins containing TRAF-like folds are unknown, and may not be directly relevant to either apoptosis or inflammation, although Siah-family proteins (which function as E3s in targeting proteins for ubiquitination) have been reported to regulate apoptosis and NFкB in some contexts (Hu et al. 1997; Polekhina et al. 2002).
Table 10. Comparison of TIR-Containing Protein in Humans and Mice

\begin{tabular}{lcccl}
\hline Protein & Human & Mouse & NCBI gi & \multicolumn{1}{c}{ RIKEN } \\
\hline IL-1R & + & + & 6680417 & C130072K02 \\
TLR1 & + & + & 11528627 & N/A \\
TLR2 & + & + & 20140895 & $1300018 \mathrm{H} 12$ \\
TLR3 & + & + & 20140736 & D130071D16 \\
TLR4 & + & + & 20140876 & $5230401 \mathrm{C04}$ \\
TLR5 & + & + & 20140822 & 9930017 K03 \\
TLR6 & + & + & MGI:1341296 & N/A \\
TLR7 & + & + & 20140470 & $9830132 N 19$ \\
TLR8 & + & + & MGI:2176887 & N/A \\
TLR9 & + & + & MGl:1932389 & N/A \\
TLR10 & + & - & Not found & N/A \\
MyD88 & + & + & 6754772 & G430132D13 \\
TRIF & + & - & Not found & N/A \\
TRIF2 & + & + & 27734184 & B430113A10 \\
Mal & + & + & 1690513 & N/A \\
TIRP & + & + & Not found & N/A \\
Total & 16 & 14 & - & 0 \\
\hline
\end{tabular}

The TIR-containing proteins of humans and mice are compared. Representative sequence identification numbers are provided. (N/A) Not applicable, indicating the cDNA was already present in NCBI. Mal is also known as TIRAp.

${ }^{a}$ New TRIF from humans, accession number is HS:NT_030385.427498150. Minus sign indicates that a murine ortholog was not found. 
Table 11. Comparison of TRAF- and TEF-Family Proteins of Humans and Mice

\begin{tabular}{lccrl}
\hline Protein & Human & Mouse & NCBI gi & \multicolumn{1}{c}{ RIKEN } \\
\hline TRAF1 & + & + & 6678425 & 4732496 E14 \\
TRAF2 & + & + & 731003 & A130081B14 \\
TRAF3 & + & + & 6686038 & N/A \\
TRAF4 & + & + & 7274404 & $9430080 B 18$ \\
TRAF5 & + & + & 1549146 & N/A \\
TRAF6 & + & + & 6678429 & A530087L19 \\
MEPRIN-1a & + & + & 15929651 & N/A \\
MEPRIN-1b & + & + & 1083414 & N/A \\
SIAH-1 & + & + & 2137774 & N/A \\
SIAH-1b & - & + & 423568 & N/A \\
SIAH-2 & + & + & 2137775 & N/A \\
TEF1 & + & + & 20891715 & 2210010009 \\
TEF2 & + & + & 15799255 & 2700043601 \\
TEF3 & + & + & Not found & 4930400A15 \\
TEF4 & + & - & Not found & Not found \\
TEF5 & - & + & 17483747 & $9030207 F 01$ \\
TEF6 & - & + & 20874936 & N/A \\
TEF7 & - & + & 20874228 & N/A \\
TEF8 & - & + & 20962014 & N/A \\
Total & 14 & 18 & N/A & 1 \\
\hline
\end{tabular}

The TRAFs and other proteins containing a TRAF-like domain (TRAF encompassing factors; TEFs) of humans and mice are compared. The murine CDNAs found exclusively in the RIKEN database are indicated. (N/A) Not applicable, indicating the data was already present at NCBI. Minus sign indicates that either a human or mouse ortholog could not be found.

Cryopyrin, PAN1-PAN11), HIN200, B-Box, or SPRY domains (Pawlowski et al. 2001). Mice appear to contain substantially fewer PAAD-family genes, as revealed through the available cDNA sequence data. Only 12 of the PAADs were identified within the mouse EST/cDNA data, presenting the orthologs of Pyrin, Cryopyrin, ASC, NAC, IFI16, PAN1, PAN2, PAN3, PAN5, PAN6, PAN7, and PAN11. Of note, the available murine cDNA sequence data corresponding to the apparent NAC ortholog lack the carboxy-terminal CARD domain found in the human protein, suggesting that (1) incomplete cDNAs were sequenced or (2) that a true difference exists in the structures of the human and mouse proteins, or (3) that a true ortholog of NAC is not present in mice, and instead, the candidate cDNA clones should be viewed as having originated from a paralogous gene more similar to the PANs and Cryopyrin in domain organization. Similarly, the Pyrin protein of mice contains the PAAD and B-box domains found in the human protein, but is lacking the carboxy-terminal SPRY domain of its human counterpart. The expansion of PAN family genes in humans correlates with a cluster of eight of these genes on human chromosome 19, suggesting recent gene duplication events.

\section{NACHT Domains}

The NACHT domain represents a nucleotide-binding fold of unknown structure, which is found in many proteins of importance for apoptosis and inflammatory reactions (Koonin and Aravind 2000). Because this domain forms oligomers (at least in some cases), it can serve as a scaffold for bringing associated proteins such as proteases and protein kinases into close apposition, inducing their activation through the induced proximity mechanism (Inohara et al. 2000). The Caspase-9-activating protein of mammals, Apaf1, contains a

\begin{tabular}{|c|c|c|c|c|}
\hline Protein & Human & Mouse & NCBI gi & RIKEN \\
\hline PYRIN & + & + & 6110308 & $\mathrm{~N} / \mathrm{A}$ \\
\hline IFI16 & + & + & Not found & A430075K09 \\
\hline AIM2 & + & - & Not found & Not found \\
\hline ASC & + & + & 12963604 & $2310046 \mathrm{~K} 21$ \\
\hline POP1 & + & - & Not found & Not found \\
\hline POP2 & + & - & Not found & Not found \\
\hline NAC & + & + & 20346355 & $\mathrm{~N} / \mathrm{A}$ \\
\hline Cryopyrin & + & + & 20344504 & N/A \\
\hline PAN1 & + & + & Not found & $\mathrm{E} 330007 \mathrm{A02}$ \\
\hline PAN2 & + & + & Not found & E330028A19 \\
\hline PAN3 & + & + & Not found & A330055K17 \\
\hline PAN4 & + & - & Not found & Not found \\
\hline PAN5 & + & + & 20343891 & 6430548120 \\
\hline PAN6 & + & + & 20947431 & N/A \\
\hline PAN7 & + & + & Not found & E330007A02 \\
\hline PAN8 & + & - & Not found & Not found \\
\hline PAN9 & + & - & Not found & Not found \\
\hline PAN10 & + & - & Not found & Not found \\
\hline PAN11 & + & + & Not found & E330019F16 \\
\hline Total & 19 & 12 & - & 6 \\
\hline
\end{tabular}

The PAAD proteins of humans and mice are compared. Representative mouse genes are indicated by the I.D. number from either NCBI or RIKEN CDNA clones databases. The PAN-family proteins are also known as PYPAFs or NALPs. Designations reported thus far in the literature include: PAN1 (NALP2, PYPAF2), PAN2 (NALP4, PYPAF4), PAN3 (PYPAF5), PAN6 (PYPAF7), and PAN7 (PYPAF3). The NAC protein is also known as DEFCAP, CARD7, and NALP1. Cryopyrin is also known as PYPAF1 and NALP3. (N/A) Not applicable, indicating that a CDNA was already present at NCBI. Minus signs indicate that a murine ortholog could not be found.

related but distinct nucleotide-binding domain, called an NBARC, which is found in Apaf1 homologs in animals (Dark in Drosophila; Ced4 in Caenorhabditis elegans), and in pathogenresponse proteins of plants (Chinnaiyan et al. 1997).

In humans, 20 candidate NACHT family members have been identified from a combination of cDNA, EST, and genomic data (A. Rojas, K. Pawlowski, F. Xu, J.C. Reed, and A. Godzik, in prep.), including (1) Nod1 (CARD4), Nod2 (CARD15), and Ipaf (CLAN), which contain amino-terminal CARDs and carboxy-terminal LRRs flanking the NACHT domain; (2) Cryopyrin (PYPAF1; NALP3) and the PAN-family proteins, PAN1-PAN11 (NALP2-NALP12) (PYPAF2-PYPAF12), which contain amino-terminal PAADs and carboxy-terminal LRRs flanking the NACHT domain, (3) NAC (NALP1, CARD7, DEFCAP), which contains an amino-terminal PAAD, followed by NACHT, and then LRRs and a carboxy-terminal CARD; (4) Naip, which has three BIRs preceeding the NACHT, followed by LRRs; (5) CIITA (MATER), which contains an aminoterminal $\alpha$-helical domain with CARD-like features upstream of the NACHT, followed by LRRs; and (6) the NACHT-only proteins, NOP1 and NOP2 (Table 13). In mice, orthologs for these proteins were found for only 16 of the 20 candidates. These included Naip, Nod1, Nod2, Ipaf, ASC, NAC, Cryopyrin, Pyrin, PAN1, PAN2, PAN3, PAN5, PAN11, and CIITA (MATER). Thus, on the basis of the available data, it appears that humans have evolved additional diversity in NACHT-family proteins, relative to mice. As mentioned above, a cluster of eight PAN-family genes is found on chromosome 19p13, suggesting recent gene amplification events (A. Rojas, K. Pawlowski, F. Zu, J.C. Reed, and A. Godzik, in prep.). 
Table 13. Comparison of NACHT-Family Proteins of Humans and Mice

\begin{tabular}{lcccl}
\hline Protein & Human & Mouse & NCBI gi & \multicolumn{1}{c}{ RIKEN } \\
\hline CLAN & + & + & 20901567 & 9530011 P19 \\
Nod1 & + & + & Not found & F830007N14 \\
Nod2 & + & + & 22003911 & F830032C23 \\
NOP1 & + & + & 20893386 & D230007K08 \\
NOP2 & + & + & 20888106 & N/A \\
NAC & + & + & 20346355 & N/A \\
NAIPa & + & + & 6754789 & A130017A22 \\
Cryopyrin & + & + & 20344504 & N/A \\
PAN1 & + & + & Not found & E330007A02 \\
PAN2 & + & + & Not found & E330028A19 \\
PAN3 & + & + & Not found & A330055K17 \\
PAN4 & + & - & Not found & Not found \\
PAN5 & + & + & 20343891 & 6430548120 \\
PAN6 & + & + & 20947430 & N/A \\
PAN7 & + & + & Not found & E330007A02 \\
PAN8 & + & - & Not found & Not found \\
PAN9 & + & - & Not found & Not found \\
PAN10 & + & - & Not found & Not found \\
PAN11 & + & + & Not found & E330019F16 \\
CIITA & + & + & 1870519 & A530020G08 \\
Total & 20 & 16 & - & 6 \\
\hline
\end{tabular}

The NACHT-family proteins of humans and mice are compared. (N/A) Not applicable.

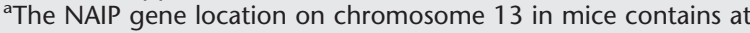
least six closely related genes, more than one of which may encode proteins containing the NACHT domain. The number of cDNAs found uniquely in the RIKEN database is indicated $(n=6)$. (N/A) Not applicable, indicating that a cDNA was already available at NCBI. Minus sign indicates that a mouse ortholog was not found.

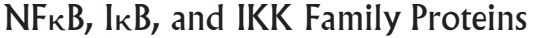

$\mathrm{NF \kappa}$ f family transcription factors play important roles in host defense and cell survival (for review, see Ghosh and Karin 2002; Karin and Lin 2002). The DNA-binding activity of these transcription factors is rapidly induced in mammalian cells by a variety of cytokines and by certain molecules produced by bacteria, inducing transcription of several genes involved in inflammation and apoptosis, including TNF-family cytokines (TNF, LT $\alpha, \mathrm{LT} \beta$, FasL), molecules involved in TNF-family receptor signaling (TRAF1), Caspase-inhibitors (c-IAP2, FLIP), and Bcl-2-family members (Bfl-1, Bcl-X).

The NFкB (Rel)-family represents a group of structurally related transcription factors containing an evolutionarily conserved amino-terminal domain spanning $\sim 300$ aminoacids, which is termed the Rel homology domain (RHD). This domain is involved in DNA binding and dimerization, and is also responsible for interactions with a family of endogenous NFkB suppressors, the IкB family (Ghosh et al. 1998; Ghosh and Karin 2002). Five members of the NFkB family are evident in human and mouse databases: RelA (p65), RelB (p50), NFкB-1 (p50/p105), NFкB-2 (p52/p100), and c-Rel (Table 14). The nuclear factor of activated T cells (NF-AT) also contains a RHD-like domain, although it is not commonly considered a member of the Rel-family.

The NFкB-family transcription factors are comprised of homo- and hetero-dimeric pairs of Rel-family proteins. Regulation of these transcription factors is complex, involving a diversity of mechanisms. In general, however, activity of $\mathrm{NF}$ B-family proteins is controlled by a counteracting family

\begin{tabular}{|c|c|c|c|c|}
\hline Protein & Human & Mouse & NCBI gi & RIKEN \\
\hline \multicolumn{5}{|l|}{ REL-family } \\
\hline c-rel & + & + & 227081 & N/A \\
\hline RelA & + & + & 6677709 & F730039C18 \\
\hline RelB & + & + & 18042801 & $\mathrm{~N} / \mathrm{A}$ \\
\hline p50/p105 & + & + & 111166 & F830007L24 \\
\hline p52/p100 & + & + & 5081604 & N/A \\
\hline \multicolumn{5}{|l|}{ ІКВ-family } \\
\hline IКB $\alpha$ & + & + & 1022734 & 0610009F10 \\
\hline $1 \kappa B \beta$ & + & + & 14548082 & A230051M19 \\
\hline I B $B \varepsilon$ & + & + & 14548076 & $2210407 G 04$ \\
\hline $\mathrm{I} \kappa \mathrm{Bz}$ & + & + & 13447398 & $\mathrm{~N} / \mathrm{A}$ \\
\hline Bcl-3 & + & + & 15809014 & N/A \\
\hline ІкB-like 1 & + & + & 6754844 & $N / A$ \\
\hline ІкB-like 2 & + & + & 10129816 & $\mathrm{~N} / \mathrm{A}$ \\
\hline ІкB-like-like2 & + & - & Not found & Not found \\
\hline \multicolumn{5}{|l|}{ IKK-family } \\
\hline IКBK $\alpha$ & + & + & 14285502 & 9530016L20 \\
\hline ІкBK $\beta$ & + & + & 14285499 & $\mathrm{~N} / \mathrm{A}$ \\
\hline $1 \kappa B K \gamma$ & + & + & 6754316 & 9930039F20 \\
\hline $\mathrm{I}_{\kappa} B K \varepsilon$ & + & + & 9789983 & E430020M09 \\
\hline TBK-1 & + & + & 9790253 & 1200008B05 \\
\hline
\end{tabular}

Note that another IкB-family protein $I_{\kappa} B \gamma($ data not shown), can be produced in mice (but not humans) from an alternative internal promoter in the p50/p105 gene (NCBI: gil247617l; RIKEN F830007L24). (N/A) Not applicable, indicating that a CDNA was available from NCBI. Minus sign indicates that a mouse ortholog was not found.

of suppressors, the ІкB-family, that sequesters these transcription factors in the cytosol. IkB-family proteins contain conserved Ankyrin-repeat structures, which bind RHDs. Eight members of the IкB family have been found in humans. Seven of these are also found in mice, including І $\mathrm{B} \alpha$, ІкB $B$, ІкB $\varepsilon$, IкBz, Bcl3, ІкB-like-1, and IкB-like-2 (Table 14). Additionally, mouse databases also reveal an alternative form of NFкB1, termed IкB $\gamma$ that is identical to the carboxy-terminal half of NFкB-1, and that is produced by transcription of the $N F \kappa B-1$ ( $p 50 / p 105)$ gene from an alternative internal promoter (Ghosh et al. 1998).

Release of NFкB typically entails degradation of ІкBfamily proteins, resulting from a mechanism involving phosphorylation by IкB-Kinases (IKKs or ІкB-Ks; Table 14), followed by ubiquitin-dependent proteasome-mediated destruction. IKKs contain a conserved serine-kinase domain and a putative leucine-zipper domain. So far, five members of the IKK family have been found in human and mouse databases. Of those, IкBK $\alpha$, ІкBK $\beta$, and ІкBK $\gamma$ form a protein complex in which ІкBK $\alpha$ and ІкBK $\beta$ represent the catalytic subunits, whereas IкBK $\gamma$ is a regulatory subunit (lacking a kinase domain) and is not structurally related to the $\alpha$ and $\beta$ subunits (Karin and Ben-Neriah 2000; Ghosh and Karin 2002). ІкBKe (Shimada et al. 1999) and Tank Binding Kinase (TBK)-1 (Pomerantz and Baltimore 1999) also are members of the IкB kinase family (Table 14).

\section{BAGs}

The BAG domain is comprised of an anti-parallel two $\alpha$-helix structure that docks with high affinity onto the ATPase domain of 70-kD heat shock proteins (Hsp70), modulating their function as molecular chaperones and helping to target Hsp70-family proteins onto specific target proteins 
(Takayama and Reed 2001). Hsp70-family molecular chaperones play roles in suppression of apoptosis, and examples of involvement in BAG-family proteins in suppressing cell death have been reported for BAG1 (Rap46), BAG3 (Bis), BAG4 (Sodd), and BAG6 (Scythe) (for review, see Briknarova et al. 2002). Humans contain six identifiable BAG-family proteins, which contain the Hsp70-binding BAG domain in association with various other domains. Mice also contain six orthologous BAG-family members, with cDNA sequence data for one of these uniquely found in the RIKEN database (Table 15). Thus, the BAG-family proteins appear to be highly conserved in humans and mice.

\section{CIDE Domains and Apoptotic Endonucleases}

DNA fragmentation is often considered a hallmark of apoptosis, reflecting the activation of endonucleases that cleave DNA between nucleosomes (Wyllie 1980). A unique domain is found in the apoptotic endonuclease DFF40 (CAD) and its homologs (Liu et al. 1997; Inohara et al. 1998; Sakahira et al. 1998), called the CIDE or CIDE-N domain. The CIDE-N domain represents a $\sim 75$ amino acid fold consisting of a twisted five-stranded $\beta$ sheet with two $\alpha$-helices arranged in an $\alpha / \beta$ roll (Lugovskoy et al. 1999). The CIDE-containing endonuclease DFF40 (CAD) is held in an inactive state by a specific chaperone protein, DFF45 (ICAD), which also contains the CIDE domain, and which associates via CIDE-CIDE interactions (Zhou et al. 2001). The endonuclease DFF40 (CAD) becomes released upon cleavage of chaperone DFF45 (ICAD) by Caspases, thus linking endonuclease activation to activation of the cell death proteases. Five CIDE family members are evident in the transcriptomes of humans and mice (Table 16).

In addition to CIDE-family endonucleases, two proteins have been identified that are sequestered in mitochondria, which can contribute directly or indirectly to genome digestion. These are EndoG, an evolutionary endonuclease (Li et al. 2001) and AIF, a flavoprotein that somehow promotes largescale cleavage of genomic DNA during apoptosis (Susin et al. 1999). Humans and mice contain cDNAs encoding EndoG and AIF. Overall, therefore, the proteins associated with apoptosis-associated genome destruction appear to be wellconserved in humans and mice.

\section{Miscellaneous Apoptosis-Relevant Proteins}

We also compared the human and murine databases with respect to a variety of miscellaneous proteins of reported relevance to apoptosis regulation, including Cytochrome c (the Apaf1-activating protein), several $\mathrm{Bcl}$-2-binding proteins (see above), and p53 and its relatives p63 and p73 (transcription factors that can regulate the expression of multiple apoptosis

\begin{tabular}{|c|c|c|c|c|}
\hline Protein & Human & Mouse & NCBI gi & RIKEN \\
\hline BAG1 & + & + & 5915764 & 2310004L01 \\
\hline BAG2 & + & + & 2170378 & D030052C04 \\
\hline BAG3 & + & + & 20843831 & 4931440G06 \\
\hline BAG4 & + & + & 19850178 & 2410112115 \\
\hline BAG5 & + & + & 20859151 & 4930405J06 \\
\hline GAB6 & + & + & Not found & $2410045 \mathrm{D} 21$ \\
\hline Total & 6 & 6 & - & 1 \\
\hline
\end{tabular}

Table 16.
Humans and Mice
\begin{tabular}{lccccl}
\hline Protein & Human & Mouse & NCBI $^{\text {a }}$ & \multicolumn{1}{c}{ RIKEN } \\
\hline CPAN & + & + & 6681185 & $5730477 D 02$ \\
DFF45 & + & + & 2754588 & D030054J11 \\
FSP27 & + & + & 2829467 & A530033M24 \\
DFFA-likeA & + & + & 3114591 & N/A \\
DFFA-likeB & + & + & 3114593 & 1110030 C18 \\
Total & 5 & 5 & - & 0 \\
\hline
\end{tabular}

The CIDE-containing proteins of humans and mice are compared. a Some of these CDNA sequences were originally found in non$\mathrm{NCBI}$ databases at Jackson Laboratories. (N/A) Not applicable.

genes), finding conservation of these proteins in humans and mice.

\section{Combinations of Domains}

It is interesting to note that 39 of the proteins described above contain more than one of the domains mentioned above. For example, several Caspases combine the Caspase protease fold with either CARD or DED domains. Para-caspase combines the DD with a Caspase-like fold. Several proteins also combined the NACHT domain with either CARD or PAAD domains. Only one predicted protein was identified in either human or mice that combined the DD and DED, namely FADD. Only RAIDD combined both the CARD and DD domains. NAC and ASC were the two proteins found that combine the CARD and PAAD domains. No predicted proteins were found that combine a CARD with a DED domain or that pair a DED with a PAAD domain. Only one protein contained both BIR and NACHT domains, namely NAIP. Only cIAP1 and cIAP2 combine the BIR and CARD domains. Only MyD88 combines the DD and TIR domains. NFкB- 1 and NFkB-2 have DDs in association with RHDs. We speculate that these few proteins that contain more than one of the signature domains implicated in apoptosis or inflammation represent critical points of cross-talk between the domain-families. This speculation is supported by gene ablation studies in mice in some instances (Kuida et al. 1995, 1998; Li et al. 1995; Nakagawara et al. 1997; Adachi et al. 1998; Hakem et al. 1998; Takahashi et al. 1998; Zhang et al. 1998; Kawai et al. 1999; Fitzgerald et al. 2001; Kabra et al. 2001).

\section{Conclusions}

Comparisons of the cDNA (EST) record of humans and mice reveals remarkable conservation of expressed genes involved in apoptosis and inflammation. In some cases, humans contain additional genes not evident in mouse, suggestive of more complex or more precise regulation of events such as Caspase- 1 activation or signaling by TNF-family receptors. Despite the incompleteness of the mouse data, in several cases we can correlate absence of certain genes with obvious duplications in the human genome, which clearly happened after divergence of mouse and human ancestors. It is interesting to note that many of these human-specific expansions can be related to apoptosis triggered by infections or external stimuli. However, in other cases, mice have expanded gene numbers (e.g. A1, NAIP, TEFs) relative to humans, implying greater redundancy in some aspects of apoptosis regulation. Knowledge of the similarities and differences in the repertoire of 
expressed genes involved in apoptosis and inflammation in humans and mice lays a foundation for understanding the utility and limitations of the mouse models of disease that are used for validating targets for drug discovery and for testing new therapeutic agents prior to entering clinical trials in humans.

\section{METHODS}

Several parallel approaches were taken for comparative analysis of apoptosis genes in human and mouse. First, amino acid sequences of human apoptotic genes from our collection, as described earlier, were used for T-BLAST-N searches (Altschul et al. 1997) of the RIKEN EST collection in a search for homologous sequences. Second, amino acid translation of the RIKEN data were subjected to an automated annotation procedure, using Psi-BLAST to find homologous sequences of human apoptotic genes, followed by structure-based analysis using FFAS in conjunction with a library containing threedimensional structures of the relevant protein folds. Third, a procedure similar to the third one was used for finding murine genes in public databases, including NCBI nonredundant (NR) protein database and Jackson Laboratories.

All identified murine genes were checked by phylogeny and multiple sequence-alignment methods to assign orthologs to human proteins where possible (Thompson et al. 1994; Li et al. 2000). For most of the protein domain families, multiple sequence alignments were prepared using T-coffee (Notredame et al. 2000), and the resulting alignments were used as an input to generate NJ trees using clustal. (Thompson et al. 1997)

\section{REFERENCES}

Adachi, O., Kawai, T., Takeda, K., Matsumoto, M., Tsutsui, H., Sakagami, M., Nakanishi, K., and Akira, S. 1998. Targeted disruption of the MyD88 gene results in loss of IL-1- and IL-18-mediated function. Immunity 9: 143-150.

Aderem, A. and Ulevitch, R.J. 2000. Toll-like receptors in the induction of the innate immune response. Nature 406: 782-787.

Altschul, S.F., Madden, T.L., Schaeffer, A.A., Zhang, J., Zhang, Z., Miller, W., and Lipman, D.J. 1997. Gapped BLAST and PSI-BLAST: A new generation of protein database search programs. Nucleic Acid Res. 25: 3389-3402.

Arch, R.H., Gedrich, R.W., and Thompson, C.B. 1998. Tumor necrosis factor receptor-associated factors (TRAFs) - A family of adapter proteins that regulates life and death. Genes \& Dev. 12: $2821-2830$.

Ashkenazi, A. and Dixit, V.M. 1998. Death receptors: Signaling and modulation. Science 281: 1305-1308.

Baud, V. and Karin, M. 2001. Signal transduction by tumor necrosis factor and its relatives. Trends Cell. Biol. 11: 372-377.

Bertin, J. and DiStefano, P.S. 2000. The PYRIN domain: A novel motif found in apoptosis and inflammation proteins. Cell Death Differ. 7: 1273-1274.

Boise, L., Gonzalez-Garcia, M., Postema, C., Ding, L., Lindsten, T., Turka, L., Mao, X., Nunez, G., and Thompson, C. 1993. Bcl-x, a $\mathrm{Bcl}-2$-related gene that functions as a dominant regulator of apoptotic cell death. Cell 74: 597-608

Bono, H., Kasukawa, T., Furuno, M., Hayashizaki, Y., and Okazaki, Y. 2002. FANTOM DB: Database of functional annotation of RIKEN mouse cDNA clones. Nucleic Acids Res. 30: 116-118.

Bradley, J.R. and Pober, J.S. 2001. Tumor necrosis factor receptor-associated factors (TRAFs). Oncogene 20: 6482-6491.

Briknarova, K., Takayama, S., Homma, S., Baker, K., Cabezas, E., Hoyt, D.W., Li, Z., Satterthwait, A.C., and Ely, K.R. 2002. BAG4/SODD protein contains a short BAG domain. J. Biol. Chem. 34: 31172-31178.

Chen, G., Cizeau, J., Park, J.H., Bozek, G., Bolton, J., Shi, L., Dubik, D., and Greenberg, A. 1999. Nix and Nip3 form a subfamily of pro-apoptotic mitochondrial proteins. J. Biol. Chem. 275: 7-10.

Cheng, G. and Baltimore, D. 1996. TANK, a co-inducer with TRAF2 of TNF- and CD40L-mediated NF-KAPPAB activation. Genes \& Dev. 10: $963-973$.
Chinnaiyan, A., Chaudhary, D., O’Rourke, K., Koonin, E., and Dixit, V. 1997. Role of CED-4 in the activation of CED-3. Nature 388: $728-729$.

Chung, J.Y., Park, Y.C., Ye, H., and Wu, H. 2002. All TRAFs are not created equal: Common and distinct molecular mechanisms of TRAF-mediated signal transduction. J. Cell. Sci. 115: 679-688.

Consortium, T.F.F. 1997. A candidate gene for familial mediterranean fever. Nat. Genet. 17: 25-31.

Della, N.G., Senior, P.V., and Bowtell, D.D. 1993. Isolation and characterisation of murine homologues of the Drosophila seven in absentia gene (sina). Development 117: 1333-1343.

Deveraux, Q.L. and Reed, J.C. 1999. IAP family proteins: Suppressors of apoptosis. Genes \& Dev. 13: 239-252.

Druilhe, A., Srinivasula, S.M., Razmara, M., Ahmad, M., and Alnemri, E.S. 2001. Regulation of IL-1 $\beta$ generation by Pseudo-ICE and ICEBERG, two dominant negative caspase recruitment domain proteins. Cell Death Differ. 8: 649-657.

Eberstadt, M., Huang, B., Chen, Z., Meadows, R., Ng, S., Zhen, L., Lenardo, M., and Fesik, S. 1998. NMR structure and mutagenesis of the FADD (Mort1) death-effector domain. Nature 392: 941-945.

Endrizzi, M.G., Hadinoto, V., Growney, J.D., Miller, W., and Dietrich, W.E. 2000. Genomic sequence analysis of the mouse Naip gene array. Genomics Res. 10: 1095-1102.

Espejo, F., Green, M., Preece, N.E., and Assa-Munt, N. 2002. NMR assignment of human ASC2, a self contained protein interaction domain involved in apoptosis and inflammation. J. Biomol. NMR 23: $151-152$

Fesik, S.W. 2000. Insights into programmed cell death through structural biology. Cell 103: 273-282.

Fiorentino, L., Oliveira, V., Ariza, M.E., Stehlik, C., Xu, F., Godzik, A., and Reed, J.C. 2002. A novel PAAD-containing protein that modulates NF-kB induction by cytokines. J. Biol. Chem. 277: 35333-35340.

Fischer, H., Koenig, U., Eckhart, L., and Tschachler, E. 2002. Human caspase-12 has acquired deleterious mutations. Biochem. Biophys. Res. Comm. 293: 722-726.

Fitzgerald, K.A., Palsson-McDermott, E.M., Bowie, A.G. Jefferies, C.A., Mansell, A.S., Brady, G., Brint, E., Dunne, A., Gray, P., Harte, M.T., et al. 2001. Mal (MyD88-adapter-like) is required for toll-like receptor-4 signal transduction. Nature 412: 78-82.

Ghosh, S. and Karin, M. 2002. Missing pieces in the NF-кB puzzle. Cell 109: S81-S96.

Ghosh, S., May, M.J., and Kopp, E.B. 1998. NF-kB and Rel proteins: Evolutionarily conserved mediators of immune responses. Ann. Rev. Immunol. 16: 225-260.

Green, D.R. and Reed, J.C. 1998. Mitochondria and apoptosis. Science 281: $1309-1312$.

Guo, B., Godzik, A., and Reed, J.C. 2001. Bcl-G, a novel pro-apoptotic member of the Bcl-2 family. J. Biol. Chem. 276: $2780-2785$.

Hakem, R., Hakem, A., Duncan, G.S., Henderson, J.T., Woo, M. Soengas, M.S., Elia, A., de la Pompa, J.L., Kagi, D., Khoo, W. et al. 1998. Differential requirement for caspase 9 in apoptotic pathways in vivo. Cell 94: $339-352$.

Hoffman, H.M., Mueller, J.L., Broide, D.H., Wanderer, A.A., and Kolodner, R.D. 2001. Mutation of a new gene encoding a putative pyrin-like protein causes familial cold autoinflammatory syndrome and Muckle-Wells syndrome. Nat. Genet. 29: 301-305.

Hofmann, K., Bucher, P., and Tschopp, J. 1997. The CARD domain: A new apoptotic signalling motif. Trends Biochem. Sci. 22: $155-156$.

Hu, G., Zhang, S., Vidal, M., Baer, J.L., and Fearon, E.R. 1997. Mammalian homologs of seven in absentia regulate DCC via the ubiquitin-proteasome pathway. Genes \& Dev. 11: 2701-2714.

Huang, D.C. and Strasser, A. 2000. BH3-only proteins-essential initiators of apoptotic cell death. Cell 103: 839-842.

Huang, S., Scharf, J.M., Growney, J.D., Endrizzi, M.G., and Dietrich, W.F. 1999. The mouse Naip gene cluster on Chromosome 13 encodes several distinct functional transcripts. Mamm. Genome 10: $1032-1035$

Humke, E.W., Shriver, S.K., Starovasnik, M.A., Fairbrother, W.J., and Dixit, V.M. 2000. ICEBERG: A novel inhibitor of interleukin-1 $\beta$ generation. Cell 103: 99-111.

Inohara, N., Koseki, T., Chen, S., Wu, X., and Nunez, G. 1998. CIDE, a novel family of cell death activators with homology to the 45 $\mathrm{kDa}$ subunit of the DNA fragmentation factor. EMBO J. 17: 2526-2533

Inohara, N., Koseki, T., Lin, J., del Peso, L., Lucas, P.C., Chen, F.F., Ogura, Y., and Nunez, G. 2000. An induced proximity model for

\section{Genome Research}


NF- $\mathrm{B}$ activation in the Nod1/RICK and RIP signaling pathways. J. Biol. Chem. 275: 27823-27831.

Kabra, N.H., Kang, C., Hsing, L.C., Zhang, J., and Winoto, A. 2001. T cell-specific FADD-deficient mice: FADD is required for early $\mathrm{T}$ cell development. Proc. Natl. Acad. Sci. 98: 6307-6312.

Kanamori, M., Suzuki, H., Saito, R., Mauramatsu, M., and Hayashizaki, Y. 2002. T2BP, a novel TRAF2 binding protein can activate NF-кB and AP-1 without TNF stimulation. Biochem. Biophys. Res. Commun. 290: 1108-1113.

Karin, M. and Ben-Neriah, Y. 2000. Phosphorylation meets ubiquitination: The control of NF-kB activity. Ann. Rev. Immunol. 18: $621-663$

Karin, M. and Lin, A. 2002. NF-кB at the crossroads of life and death. Nat. Immunol. 3: 221-227.

Kawai, J., Shinagawa, A., Shibata, K., Yoshino, M., Itoh, M., Ishii, Y., Rakawa, T., Hara, A., Fukunishi, Y., Konno, H., et al. 2001. Functional annotation of a full-length mouse cDNA collection. Nature 409: 685-690.

Kawai, T., Adachi, O., Ogawa, T., Takeda, K., and Akira, S. 1999. Unresponsiveness of MyD88-deficient mice to endotoxin. Immunity 11: 115-122.

Koonin, E.V. and Aravind, L. 2000. The NACHT family-A new group of predicted NTPases implicated in apoptosis and MHC Transcription activation. Trends Biol. Sci. 25: 223-224.

Kovacsovics, M., Martinon, F., Micheau, O., Bodmer, J.L., Hofmann, K., and Tschopp, J. 2002. Overexpression of Helicard, a CARD-containing helicase cleaved during apoptosis, accelerates DNA degradation. Curr. Biol. 12: 838-843.

Kroemer, G. and Reed, J.C. 2000. Mitochondrial control of cell death. Nat. Med. 6: 513-519.

Kuida, K., Lippke, J.A., Ku, G., Harding, M.W., Livingston, D.J., Su, M.S., and Flavell, R.A. 1995. Altered cytokine export and apoptosis in mice deficient in interleukin-1 $\beta$ converting enzyme. Science 267: 2000-2003.

Kuida, K., Haydar, T.F., Kuan, C.Y., Gu, Y., Taya, C., Karasuyama, H., Su, M.S., Rakic, P., and Flavell, R.A. 1998. Reduced apoptosis and cytochrome c-mediated caspase activation in mice lacking caspase 9. Cell 94: 325-337.

La Casse, E.C., Baird, S., Korneluk, R.G., and MacKenzie, A.E. 1998. The inhibitors of apoptosis (IAPs) and their emerging role in cancer. Oncogene 17: 3247-3259.

Lee, S.H., Stehlik, C., and Reed, J.C. 2001. COP, a CARD-containing protein and inhibitor of pro-interleukin-1b processing. J. Biol. Chem. 276: 34495-34500.

Lee, S.Y., Lee, S.Y., and Choi, Y. 1997. TRAF-interacting Protein (TRIP): A novel component of the tumor necrosis factor receptor (TNFR)-and CD30-TRAF signaling complexes that inhibits TRAF2-mediated NF-KB activation. J. Exp. Med. 185: 1275-1285.

Li, L.Y., Luo, X., and Wang, X. 2001. Endonuclease G is an apoptotic DNase when released from mitochondria. Nature 412: $95-99$.

Li, P., Allen, H., Banerjee, S., Franklin, S., Herzog, L., Johnston, C., McDowell, J., Paskind, M., Rodman, L., Salfeld, J., et al. 1995. Mice deficient in IL-1b-converting enzyme are defective in production of mature IL-1b and resistant to endotoxic shock. Cell 80: 401-411.

Li, W.Z., Pio, F., Pawlowski, K., and Godzik, A. 2000. Saturated BLAST: An automated multiple intermediate sequence search used to detect distant homology. Bioinformatics 16: 1105-1110.

Ling, L. and Goeddel, D.V. 2000. MIP-T3, a novel protein linking tumor necrosis factor receptor-associated factor 3 to the microtubule network. J. Biol. Chem. 275: 23852-23860.

Liu, X., Zou, H., Slaughter, C., and Wang, X. 1997. DFF, a heterodimeric protein that functions downstream of caspase-3 to trigger DNA fragmentation during apoptosis. Cell 89: 175184

Locksley, R.M., Killeen, N., and Lenardo, M.J. 2001. The TNF and TNF receptor superfamilies: Integrating mammalian biology. Cell 104: $487-501$.

Lugovskoy, A., Zhou, P., Chou, J., McCarty, J., Li, P., and Wagner, G. 1999. Solution structure of the cide-n domain of cide-b and a model for cide-n/cide-n interactions in the DNA fragmentation pathway of apoptosis. Cell 99: 747-755.

Manji, G.A., Wang, L., Geddes, B.J., Brown, M., Merriam, S., Al-Garawi, A., Mak, S., Lora, J.M., Briskin, M., Jurman, M., et al. 2002. PYPAF1: A PYRIN-containing Apaf1-like protein that assembles with ASC and regulates activation of NF-kB. J. Biol. Chem. 277: 11570-11575.

Martinou, J.C. and Green, D.R. 2001. Breaking the mitochondrial barrier. Nat. Rev. Mol. Cell. Biol. 2: 63-67.
Metzstein, M., Stanfield, G., and Horvitz, H. 1998. Genetics of programmed cell death in C. elegans: Past, present and future. Trends Genet. 14: 410-416.

Migone, T.S., Zhang, J., Luo, X., Zhang, L., Chen, C., Hu, B., Hong, J.S., Perry, J.W., Chen, S.F., Zhou, J.X., et al. 2002. TL1A is a TNF-like ligand for DR3 and TR6/DcR3 and functions as a T cell costimulator. Immunity 16: 479-492.

Miller, L. 1999. An exegesis of IAPs: Salvation and surprises from BIR motifs. Trends Cell. Biol. 9: 323-328.

Miller, L.K. 1997. Baculovirus interaction with host apoptotic pathways. J. Cell. Physiol. 173: 178-182.

Nakagawara, A., Nakamura, Y., Ikeda, H., Hiwasa, T., Kuida, K., Su, M., Zhao, H.Q., Cnaan, A., and Sakiyama, S. 1997. High levels of expression and nuclear localization of interleukin-1 $\beta$ converting enzyme (ICE) and CPP32 in favorable human neuroblastomas. Cancer Res. 57: 4578-4584.

Nickerson, K., Sisk, T.J., Inohara, N., Yee, C.S., Kennell, J., Cho, M.C., Yannie, P.J., Nunez, G., and Chang, C.H. 2001. Dendritic cell-specific MHC class II transactivator contains a caspase recruitment domain that confers potent transactivation activity. J. Biol. Chem. 276: 19089-19093.

Notredame, C., Higgins, D., and Heringa, J. 2000. T-Coffee: A novel method for multiple sequence alignments. J. Mol. Biol. 302: $205-217$.

O'Reilly, L.A. and Strasser, A. 1999. Apoptosis and autoimmune disease. Inflamm. Res. 48: 5-21.

Orlofsky, A., Weiss, L.M., Kawachi, N., and Prystowsky, M.B. 2002. Deficiency in the anti-apoptotic protein A1-a results in a diminished acute inflammatory response. J. Immunol. 168: $1840-1846$.

Oukka, M., Kim, S.T., Lugo, G., Sun, J., Wu, L.C., and Glimcher, L.H. 2002. A mammalian homolog of Drosophila schnurri, KRC, regulates TNF receptor-driven responses and interacts with TRAF2. Mol. Cell 9: 121-131.

Pathan, N., Marusawa, H., Krajewska, M., Matsuzawa, S.I., Kim, H., Okada, K., Torii, S., Kitada, S., Krajewski, S., Welsh, K., et al. 2001. TUCAN: An anti-apoptotic CARD family protein over-expressed in cancer. J. Biol. Chem. 276: 32220-32229.

Pawlowski, K., Pio, F., Chu, Z.L., Reed, J.C., and Godzik, A. 2001. PAAD-a new protein domain associated with apoptosis, cancer and autoimmune diseases. Trends Biochem. Sci. 26: 85-87.

Perfettini, J.L., Reed, J.C., Israël, N., Martinou, J.C., Dautry-Varsat, A., and Ojcius, D.M. 2002. Role of Bcl-2 family members in caspase-independent apoptosis during Chlamydia infection. Infect. Immunol. 70: 55-61.

Polekhina, G., House, C.M., Traficante, N., Mackay, J.P., Relaix, F., Sassoon, D.A., Parker, M.W., and Bowtell, D.D. 2002. The siah ubiquitin ligase component is structurally related to the TRAF family of proteins and modulates TNF-a-signalling. Nat. Struct. Biol. 9: 68-75.

Pomerantz, J. and Baltimore, D. 1999. NF-kB activation by a signaling complex containing TRAF2, TANK and TBK1, a novel IKK-related kinase. EMBO J. 18: 6694-6704.

Pype, S., Declercq, W., Ibrahim, A., Michiels, C., Van Rietschoten, J.G., Dewulf, N., de Boer, M., Vandenabeele, P., Huylebroeck, D., and Remacle, J.E. 2000. TTRAP, a novel protein that associates with CD40, tumor necrosis factor (TNF) receptor-75 and TNF receptor-associated factors (TRAFs), and that inhibits nuclear factor-kB activation. J. Biol. Chem. 275: 18586-18593.

Reed, J. 1999. Splicing and dicing apoptosis genes. Nat. Biotechnol. 17: $1064-1065$

Reed, J.C. 2000. Mechanisms of apoptosis (Warner/Lambert Award). Amer. J. Pathol. 157: 1415-1430.

. 2002. Apoptosis-based therapies. Nat. Rev. Drug Disc. 1: $111-121$

Reed, J.C., Cardone, M.H., Roy, N., Stennicke, H.R., Salvesen, G.S., Franke, T., and Stanbridge, E. 2000. Caspase phosporylation, cell death, and species variability (response). Science 287: 1363.

Rodriguez, J., Chen, H.H., Lin, S.C., and Lazebnik, Y. 2000. Caspase phosphorylation, cell death, and species variability (letter). Science 287: 1363.

Roth, W., Isenmann, S., Nakamura, M., Platten, M., Wick, W., Kleihues, P., Bahr, M., Ohgaki, H., Ashkenazi, A., and Weller, M. 2001. Soluble decoy receptor 3 is expressed by malignant gliomas and suppresses CD95 ligand-induced apoptosis and chemotaxis. Cancer Res. 61: 2759-2765.

Rothe, M., Xiong, J., Shu, H.B., Williamson, K., Goddard, A., and Goeddel, D.V. 1996. I-TRAF is a novel TRAF-interacting protein that regulates TRAF-mediated signal transduction. Proc. Natl. Acad. Sci. 93: 8241-8246. 


\section{Reed et al.}

Roy, N., Mahadevan, M.S., McLean, M., Shutler, G., Yaraghi, Z., Farahani, R., Baird, S., Besner-Johnson, A., Lefebvre, C., Kang, X., et al. 1995. The gene for neuronal apoptosis inhibitory protein is partially deleted in individuals with spinal muscular atrophy. Cell 80: $167-178$.

Sakahira, H., Enari, M., and Nagata, S. 1998. Cleavage of CAD inhibitor in CAD activation and DNA degradation during apoptosis. Nature 391: 96-99.

Salvesen, G.S. and Dixit, V.M. 1999. Caspase activation: The induced-proximity model. Proc. Natl. Acad. Sci. 96: 10964-10967.

Scorilas, A., Kyriakopoulou, L., Yousef, G.M., Ashworth, L.K., Kwamie, A., and Diamandis, E.P. 2001. Molecular cloning, physical mapping, and expression analysis of a novel gene, BCL2L12, encoding a proline-rich protein with a highly conserved BH2 domain of the Bcl-2 family. Genomics 72: $217-221$.

Shimada, T., Kawai, T., Takeda, K., Matsumoto, M., Inoue, J.I., Tatsumi, Y., Kanamaru, A., and Akira, S. 1999. IKK-i, a novel lipopolysaccharide-inductible kinase that is related to IkB kinases. Int. Immunol. 11: 1357-1362.

Silverman, N. and Maniatis, T. 2001. NF-kB signaling pathways in mammalian and insect innate immunity. Genes \& Dev. 15: $2321-2342$.

Srinivasula, S.M., Poyet, J.L., Razmara, M., Datta, P., Zhang, Z., and Alnemri, E.S. 2002. The PYRIN-CARD protein ASC is an activating adaptor for Caspase-1. J. Biol. Chem. 277: 21119-21122.

Staub, E., Dahl, E., and Rosenthal, A. 2001. The DAPIN family: A novel domain links apoptotic and interferon response proteins. Trends Biochem. Sci. 26: 83-85.

Susin, S., Lorenzo, H., Zamzami, N., Marzo, I., Snow, B., Brothers, G., Mangion, J., Jacotot, E., Costantini, P., Loeffler, M., et al. 1999. Molecular characterisation of mitochondrial apoptosis-inducing factor (AIF). Nature 397: 441-446.

Takahashi, R., Deveraux, Q.L., Tamm, I., Welsh, K., Assa-Munt, N. Salvesen, G.S., and Reed, J.C. 1998. A single BIR domain of XIAP sufficient for inhibiting caspases. J. Biol. Chem. 273: 7787-7790.

Takayama, S. and Reed, J.C. 2001. Molecular chaperone targeting and regulation by BAG family proteins. Nat. Cell. Biol. 3: E237-E241

Tartaglia, L.A., Weber, R.F., Figari, I.S., Reynolds, C., Palladino Jr., M.A., and Goeddel, D.V. 1991. The two different receptors for tumor necrosis factor mediate distinct cellular responses. Proc. Natl. Acad. Sci. 88: 9292-9296.

Thompson, C.B. 1995. Apoptosis in the pathogenesis and treatment of disease. Science 267: 1456-1462.

Thompson, J.D., Higgins, D.G., and Gibson, T.J. 1994. CLUSTAL W: Improving the sensitivity of progressive multiple sequence alignment through sequence weighting, position-specific gap penalties and weight matrix choice. Nucleic Acids Res. 22: $4673-4680$.
Thompson, J.S., Gibson, T.J., Plewniak, F., Jeanmougin, F., and Higgins, D.G. 1997. The ClustalX windows interface: Flexible strategies for multiple sequence alignment aided by quality analysis tools. Nucleic Acids Res. 24: 4876-4882.

Thornberry, N.A. and Lazebnik, Y. 1998. Caspases: Enemies within. Science 281: 1312-1316.

Uren, A.G. and Vaux, D.L. 1996. TRAF proteins and meprins share a conserved domain. Trends Biochem. Sci. 21: 244-245.

Uren, A.G., O'Rourke, K., Aravind, L., Pisabarro, M.T., Seshagirl, S., Koonin, E.V., and Dixit, V.M. 2000. Identification of paracaspases and metacaspases: Two ancient families of caspase-like proteins, one of which plays a key role in MALT lymphoma. Mol. Cell 6: 961-967.

Vabulas, R.M., Ahmad-Nejad, P., Ghose, S., Kirschning, C.J., Issels, R.D., and Wagner, H. 2002. HSP70 as endogenous stimulus of the Toll/Interleukin-1 receptor signal pathway. J. Biol. Chem. 277: $15107-15112$

Wagner, H. 2001. Toll meets bacterial CpG-DNA. Immunity 14: $499-502$.

Wang, L., Manji, G.A., Grenier, J.M., Al-Garawi, A., Merriam, S., Lora, J.M., Geddes, B.J., Briskin, M., DiStefano, P.S., and Bertin, J. 2002. PYPAF7: A novel PRYIN-containing Apaf1-like protien that regulates activation of NF-kB and Caspase-1-dependent cytokine processing. J. Biol. Chem. 27 7: 29874-29880.

Wyllie, A.H. 1980. Glucocorticoid-induced thymocyte apoptosis is associated with endogenous endonuclease activation. Nature 284: $555-556$

Xu, Y., Tao, X., Shen, B., Horng, T., Medzhitov, R., Manley, J.L., and Tong, L. 2000. Structural basis for signal transduction by the toll/interleukin-1 receptor domains. Nature 408: 111-115.

Yu, K.Y., Kwon, B., Ni, J., Zhai, Y., Ebner, R., and Kwon, B.S. 1999. A newly identified member of tumor necrosis factor receptor superfamily (TR6) suppresses LIGHT-mediated apoptosis. J. Biol. Chem. 274: 13733-13736.

Zapata, J.M., Pawlowski, K., Haas, E., Ware, C.F., Godzik, A., and Reed, J.C. 2001. A diverse family of proteins containing Tumor Necrosis Factor Receptor-associated Factor domains. J. Biol. Chem. 276: 24242-24252.

Zhang, J., Cado, C., Chen, A., Kabra, N., and Winoto, A. 1998. Fas-mediated apoptosis and activation-induced T-cell proliferation are defective in mice lacking FADD/Mort 1. Nature 392: 296-299.

Zhou, P., Lugovskoy, A.A., McCarty, J.S., Li, P., and Wagner, G. 2001. Solution structure of DFF40 and DFF45 N-terminal domain complex and mutual chaperone activity of DFF40 and DFF45. Proc. Natl. Acad. Sci. USA 98: 6051-6055.

Received January 6, 2003; accepted in revised form April 8, 2003.

\section{Genome Research}




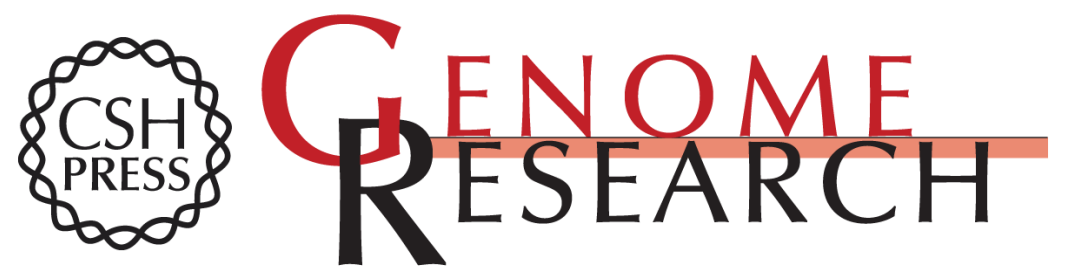

\section{Comparative Analysis of Apoptosis and Inflammation Genes of Mice and Humans}

John C. Reed, Kutbuddin Doctor, Ana Rojas, et al.

Genome Res. 2003 13: 1376-1388

Access the most recent version at doi:10.1101/gr.1053803

References This article cites 106 articles, 39 of which can be accessed free at:

http://genome.cshlp.org/content/13/6b/1376.full.html\#ref-list-1

\section{License}

Email Alerting Receive free email alerts when new articles cite this article - sign up in the box at the Service top right corner of the article or click here.

\section{Affordable, Accurate Sequencing.}

To subscribe to Genome Research go to: https://genome.cshlp.org/subscriptions 